IRA-International Journal of Management \& Social Sciences

ISSN 2455-2267; Vol.12, Issue 01 (July 2018)

Pg. no. 12-16.

Institute of Research Advances

http://research-advances.org/index.php/RAJMSS

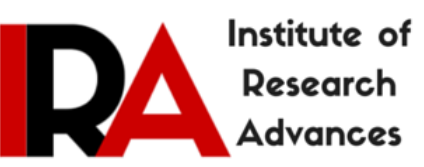

\title{
Women and Successful Ageing
}

\section{Dr. J. Raja Meenakshi}

Post Doctoral Fellow (ICSSR), Department of Social Work, Central University of Tamil Nadu, INDIA.

Type of Review: Peer Reviewed.

DOI: http://dx.doi.org/10.21013/jmss.v12.n1.p2

\section{How to cite this paper:}

Meenakshi, J.R. (2018). Women and Successful Ageing. IRA-International Journal of Management \& Social Sciences (ISSN 2455-2267), 12(1), 12-16. doi:http://dx.doi.org/10.21013/jmss.v12.n1.p2

(C) Institute of Research Advances.

\section{(cc) BY-NC}

This work is licensed under a Creative Commons Attribution-Non Commercial 4.0 International License subject to proper citation to the publication source of the work.

Disclaimer: The scholarly papers as reviewed and published by the Institute of Research Advances (IRA) are the views and opinions of their respective authors and are not the views or opinions of the IRA. The IRA disclaims of any harm or loss caused due to the published content to any party.

Institute of Research Advances is an institutional publisher member of Publishers International Linking Association Inc. (PILA-CrossRef), USA. The institute is an institutional signatory to the Budapest Open Access Initiative, Hungary advocating the open access of scientific and scholarly knowledge. The Institute is a registered content provider under Open Access Initiative Protocol for Metadata Harvesting (OAI-PMH).

The journal is indexed \& included in WorldCat Discovery Service (USA), CrossRef Metadata Search (USA), WorldCat (USA), OCLC (USA), Open J-Gate (India), EZB (Germany) Scilit (Switzerland), Airiti (China), Bielefeld Academic Search Engine (BASE) of Bielefeld University, Germany, PKP Index of Simon Fraser University, Canada. 


\begin{abstract}
Every human being has to face the ageing process and no one could escape from it. The understanding of ageing differs from culture to culture and it varies across nations. World Health Organization recognized that the developing world often defines old age, not by years, but by new roles, loss of previous roles, or inability to make active contribution to society. Women in India generally considered as secondary citizens and the life of the aged women needs wide attention. Successful ageing refers to leading the life with good physical and psychological health and also with economical independence. Pre plan is highly required to lead a successful life. This study makes an attempt to study the life of elderly women and to understand how they lead a successful life. Case study method was used to study the successful life of the respondents.
\end{abstract}

Keywords: Ageing, Physical Function, Engagement, Economic independence, Life satisfaction.

\title{
Introduction:
}

Successful ageing comprises of the well being of physiological ageing, psychological ageing and social ageing. Physiological ageing refers to changes with passage of time in the structure and processes of tissues, major organs and systems of the body that can ultimately affect our health, behavior, functional capacity and survival. It is defined on the basis of the anatomical and physiological changes that take place in the life of an individual with the passage of time [1]. Psychological ageing refers to age related changes in behavior and mental process, such as cognitive functioning, personality, and psychopathology. It includes the changes in mental functioning and sense of self which could be due to physiological changes in the function of brain. Social ageing refers to age related changes that result from forces either arising from the society in which individual lives or from the individual's responses to socially imposed constraints. Sucessful ageing includes the three main components of low probability of disease and disease related disability, high cognitive and physical capacity and active engagement with life [2]. In India elderly women constitute a distinct population and their life is quite different from elderly men. Life of women is highly constructed by the society in the name of culture and tradition. In almost all the societies, women are expected to be care givers for family members rather than living a life of her own wish and expectations. Suceessful ageing is a mirage for many elderly women as their life is not constructed by them. Due to gradual changes in the perception of ageing process of elderly women, there is a space arising for the successful ageing for elderly women. There are very few researches about the successful ageing of elderly women and this paper focuses on the life of elders who leads the life successfully. A person with successful ageing should be avoiding disease and disability, have engagement with life and have high cognitive and physical function.

\section{Objective:}

To understand the factors contributing for successful ageing.

To study some representative case studies on successful ageing.

\section{Successful Ageing:}

The perception and understanding of the term 'successful ageing' varies from person to person and it depends on various physical, psychological, social and cultural factors. Successful ageing is a life time process and so the involvement should start early in life. Physical Health in the old age is the result of experiences of earlier years of life; therefore, old age should not be looked upon as a separate compartment of life, but rather as the other end of a continuum of one's life time. The pattern of living which enhances health is formed early in life and is not easily altered. World Health Organization defines health as "a state of complete physical, mental and social well being and not merely the absence of disease or infirmity". Mental health is an indivisible part of general health and well being, and as a concept reflects the equilibrium between the individual and environment in a broad sense. Discrimination, lack of participation, issues in relationships, physical health and poverty affects the mental health of aged people. The condition of the physical health has an influence on the psychological health of the aged where the physical ill people would have stress and depression due to physical dependence on others and by having a feeling of being burden to others. Physical health of elderly women is one of the least explored fields where in India women take care of the health of the family members rather than self health. Engagement with life is an important aspect where the elders should have cordial relationship with family members, relatives and friends and they could contribute for the well being of the family and society. 
Mostly, majority of the Indian women spend time in kitchen and elderly women should have space for engage themselves in the family and society. High cognitive and physical function is essential to have a fulfilled life which reduces the dependency on others and good physical and mental health is essential for cognitive and physical function. Life satisfaction is a feeling which offers a sense of contentment and fulfilment for any person. Life satisfaction is also determined by one's value - what one considers important and wants to achieve in life. Some of the values which determine the life satisfaction are position, wealth, ego integrity, helpfulness, character, independence or autonomy, reputation in a special field and a peaceful and quite life. Most people consider that apart from education, vocation, marriage and child rearing functions, one is expected to live according to social ethics and earn a good reputation in life. It was observed that individuals who felt that they had accomplished most of these things and fulfilled their obligations to family and society express greater level of life satisfaction [3].The Madrid International Plan of Action 2003 had three policy directions which are older persons and development, advancing health and well- being of old age and ensuring enabling and supporting environments to the aged people [4]. Life satisfaction is the ultimate base for successful ageing and it depends on how the elderly women lead the life after the age of 60.

\section{Case Study 1:}

Mrs.Jessy is a retired clerk from Indian railways, living with her husband in the sub urban of Madurai District. She is 82 years old and her husband is 87 years old. All the children in her street call her 'English Grandma' since she and her husband are Anglo Indians. She has two daughters and a son. All are married and the daughters are living abroad. Her son got separated from his wife and living with the parents. Her daily routine is she wakes up at 5.30AM and goes for walking for half an hour and then cleans the court yard and house. She maintains a garden and waters it for an hour. She and her husband prepare the breakfast together. She reads three English dailies and discusses all the news with her husband. She is an honorary English Teacher in five Matriculation schools. She teaches English Grammar once in a week in all the schools and she is a favourite teacher among the students in all schools. She follows unique teaching methodologies to teach Grammar to the High school students. Other than being an English teacher, she has written and published three books on Spoken English. She publishes book at her own cost and sells it in bulk to schools at nominal cost. She said that she is very busy during week days and she could spend time with the family only during weekends. She is an active member of Anglo Indian Association and does the Administrative work in the association particularly relating to Government related works. Every year she organizes the Christmas and New Year party in the association and she does lot of social service as a part of celebration. Recently she got diabetes and she feels that she could cope up with it. She strongly feels that her husband supported for her success in life. Her husband emotionally supported her throughout her life and manages the family in a wonderful manner. Her husband is a retired school teacher and both of them take tuition classes in the evening for the school children of their residential locality. Mrs.Jessy is spending her life in a meaningful and constructive way by supporting the education of many school children. This case study says a proper planning for retirement life will make the life smooth and the cordial relationship with spouse is also one of the basis for successful old age.

\section{Case Study 2:}

Dr. Jeyalakshmi is a jovial and energetic woman ageing 65 years living in the sub urban of Madurai. She worked in the Department of Psychology in an Autonomous college and served as the Principal of the college for 10 years. She is well known for her administrative skills and she brought a tremendous change in the education pattern in the college which was highly appreciated by Academicians. She lives with her husband ageing 67 years and a son. Her son is working in Canada and once in a year he visits his parents. She had a clear life plan about her retirement life prior to retirement itself. She is economically sound with her pension amount and from the support of her son. The very next month of her retirement, she started a Non Government Organization with the objective to enhance the socio economic life of rural children by providing training on life skills. Systematically, she selects school children from rural areas and provides residential training on street theatre, folk dance and other skills to develop the children's personality. Though she gets job offers in many foreign universities, she declines it and he decided to spend his life in his home town by developing the life of rural school children. She does not have any major physical ailments and recently she got diabetes. She regularly does physical exercise for an hour in the morning. In all the works she does, she makes her husband to participate and contribute. Her husband would be one of the resource persons in all the skill development programmes. With the request from many people, she recently started life skills programme for college students and it is well received and accepted. She expressed that she never insists his son to live with him, as she is clear 
that her son has to live his life in the way he wants to, where it would give happiness for the son. She reads at least four books in a week on different subjects. She made herself engaged by doing various activities like writing books, giving lectures in many universities, providing life skill training for school children etc.,Her future plan is to start a training institute and it should become a life changing place for young generation. She is a potential human resource, one who gets self satisfaction by contributing for the welfare of the society.

\section{Case Study 3:}

Mrs.Padma worked in a private school as an art and craft teacher. After her retirement she took care of her grand children. Her husband passed away when she was 50 years old. She is a mother of a daughter and son. Her married son met with an accident while riding motorcycle and died on the spot leaving his wife and two kids. So, Mrs.Padma has to take care of the daughter in law and grand children. She could not take classes at home because she has to get a job for her daughter in law. At last she has got a job, now Mrs.Padma has to take care of the household chores. She always had a fire in her that she must contribute something to the society. One of her relatives asked her to get Aarthi plates (used in marriages) for her daughter's marriage. Instead of buying it from the market, she herself prepared the plates. It was very much appreciated by the people who attended the marriage. This gave her a chance to make such plates. She uses her imagination and creativity in making these plates. People approach her for these plates and it gives her income also. Nowadays, she is teaching women near her house this art free of cost. She spends money to buy all the raw materials necessary for the making of the plates. She pays them for their work. She is lending these plates for marriages for rent. Some people buy them from her.

This shows that Mrs.Padma is able to help others to earn money and she also earns money at the age of 64.Though she has met many sorrows in her life, it did not stop her to continue her constructive contribution .She had been interviewed by a leading daily newspaper for her creativity and now she has become very famous in her locality. Often she gets Aarthi plates orders from other towns for marriage fuctions. At the age of sixty four; she is leading a happy and contended life.

\section{Case Study 4:}

As the eldest daughter of a family of eight members, Ms.Devi remained as a spinster for various reasons. She took care of her family by working in a private company which manufactures "Domestic cleaning products". She educated her brothers and sisters. All her sisters and brothers got married and by the time everyone settled in life she crossed 40 years of age. She decided to be a spinster. She continued to work in the company till she was 58.Then her brothers and sisters asked her to give up her job and live with them for the rest of the life. She also accepted. She lives with her sisters and brothers, taking turns.

Now she is sixty four and enjoying her stay wherever she stays. She helps the kids in their studies. She teaches them proverbs and puzzles in Tamil. The neighbouring ladies also enjoy her company. She never allows to waste their time in chatting or gossiping. She teaches them how to make soap, shampoo, detergent liquid, phenol, dish wash liquid to the housewives. The women folk learn the methods enthusiastically. She helps them with all details of the raw materials and where it could be bought. When they see the end product they feel elated. It helps them to save money. As a result, the lady folk have great regard and respect for Devi.

Devi's brothers and sisters are always eagerly waiting for her arrival and her stay with them. More than them, their neighbours wait for her. Nowadays, she teaches the servant maids also the techniques. She invests a small amount in buying the raw materials for them. After they make the product, she teaches them to market the products. Apart from the salary they get as servant maid, they get sizeable amount to spend for their family.

Devi's case study is a very inspiring one. She is happy and makes others also happy. She is using her knowledge and experience for the good of her fellow human beings.

\section{Findings:}

Every woman has the right to lead successful ageing with active and healthy life, economic independence, physical and psychological health, cordial relation with others and with the feeling of Life satisfaction. In the above case studies, all the respondents have economic independence which makes them to take decisions on their own to certain extent. All the respondents contribute for the well being of others and society which makes them happy and contended. They have good physical health and they do physical activities to engage both mind 
and body, by maintaining healthy relationship with others and by contributing for the well being for of others they have effective engagement with life. In addition to this all the respondents have high cognitive and physical function which makes them to perform meaningful and constructive activities and above all they have satisfaction over their actions.

\section{Acknowledgment: The author is thankful to all the respondents of this study.}

\section{References:}

[1]. Alessio, H. (2001). Physiology of human aging. Ageing: the Social Context. 2nd edition, Pine Forge Press, Thousand Oaks, CA, 107-141.

[2]. Rowe, J. W., \& Kahn, R. L. (1997). Successful aging. The gerontologist, 37(4), 433-440.

[3]. Ramamurthi, P. V. (1989b). Determinants of Satisfaction with Present Life among Sample of Elderly Rural men in India. Paper presented at the XIV International Congress of Gerontology, Acapulco, Mexico.

[4]. Political Declaration and Madrid International Plan of Action on Ageing. Retrieved from http://www.un.Org/en/events/pastevents/pdfs/Madrid plan.pdf 